DOI: $10.21802 /$ artm.2020.1.13.134.

УДК 616.352-089-06 C-605

\title{
СВІТЛООПТИЧНІ ТА СУБМІКРОСКОПІЧНІ ОСОБЛИВОСТІ ПАТОЛОГІЧНИХ ЗМІН У ГЕМОРОЇДАЛЬНИХ ВУЗЛАХ, ВИДАЛЕНИХ РІЗНИМИ ІНСТРУМЕНТАМИ
}

\author{
В.Д. Скрипко ${ }^{1}$, О.Г. Попадинець ${ }^{2}$, П.В. Соломчак ${ }^{1}$ \\ Івано-Франківський національний медичний університет, \\ ${ }^{1}$ кафедра хірургії ННІ ПО, ${ }^{2}$ кафедра анатомії людини, \\ м. Івано-Франківськ, Украӥна, \\ ORCID ID: 0000-0003-0670-8600, \\ ORCID ID: 0000-0002-1555-2030, \\ ORCID ID: 0000-0002-2093-5984, \\ e-mail: solopetro@gmail.com
}

Резюме. Геморойектомія- це операція, при якій задоволеність пацієнтів низька, хоча це часто виконувана операція в сучасній хірургічній практиці. Основною причиною невдоволення є виражений післяопераційний біль та інші ускладнення. Значна частина ускладнень пов'язана 3 видом хірургічного інструменту, яким видаляється гемороїдальний комплекс. Актуальним є пошук інструменту, який дозволяє ефективно розсікати тканини з мінімальними пошкоджуючими ефектами. 3 метою вивчення впливу металевого скальпеля, діатермокоагуляції та біполярної коагуляції на тканину гемороїдального комплексу у досліджуваних хворих проводили гістологічні дослідження.

При класичній закритій геморойектомії за Фергюсоному стінці кишки спостерігаються геморагічнодистрофічні процеси, виражена дезорганізація сполучно-тканинних складових. При геморойектомії за Мілліганом-Морганом,виконаній моно полярною електрокоагуляційною установкою,у стінці кишки домінують набрякові зміни. При геморойектомії за Мілліганом-Морганом шляхом використання високочастотного електрозварювання м'яких тканин фіксується тонкий шар коагуляційного некрозу, збереженість оболонкової будови стінки кишки. $€$ незначний набряк міжклітинної основної речовини і явища стазу у дрібних судинах, мозаїчні острівці геморагічного просякання.

Застосування методу високочастотного електрозварювання м'яких тканин характеризується контрольованою, щадливою дією на тканини, зона латерального некрозу після біполярної коагуляції менша, ніж після застосування звичайної діатермії. Дисекція та коагуляція за допомогою біполярного високочастотного електрокоагулятора ЕК 300 M1 характеризується суворо локальним ефектом, наявністю “біологічного зварювання” шарів, органу, який розсікали, й надійним гемостазом.

Ключові слова: геморойектомія, металевий скальпель, діатермія, біполярна електрокоагуляція, морфологічні зміни.

Вступ. Хронічний геморой $(Х Г)$ все ще залишається одним із найпоширеніших захворювань людини. За даними ряду авторів, захворюваність на ХГ становить 130-150 на 1000 осіб дорослого населення, а питома вага його в структурі колопроктологічних захворювань коливається від 30 до 40 \% [1].

На особливу увагу також заслуговує той факт, що близько 80 \% хворих на ХГ перебувають у найбільш працездатному віці 25-55 років. Тривалі терміни лікування, медичної та соціальної реабілітації зумовлюють медико-соціальну значущість проблеми [2].

У зв'язку з тим, що малоінвазивні втручання $€$ нерадикальними і дають досить велику кількість випадків рецидиву, «золотим стандартом» лікування симптоматичного геморою III-IV ступеня залишається геморойектомія (ГЕ), а методика МілліганаМоргана і Фергюсона - найбільш часто використовувані методи в усьому світі [3].

Обгрунтування дослідження. ГЕ - це операція, при якій задоволеність пацієнтів низька, хоча це найбільш поширена операція в сучасній хірургіч- ній практиці. Основною причиною невдоволення пацієнтів $є$ виражений післяопераційний біль, який виникає у 20-40 \% оперованих хворих, ранні і пізні кровотечі, які зустрічаються в 0,6-10\% пацієнтів, гостра затримка сечі - в 2-36\% пацієнтів, анальний стеноз - в 0-6 \% пацієнтів, інфекція післяопераційних ран - у 0,5-5\% пацієнтів та анальна інконтиненція - у 2-12\% пацієнтів [4].

Значна частина цих ускладнень пов'язана 3 видом хірургічного інструменту, яким видаляється гемороїдальний комплекс. Тому актуальним питанням ГЕ є пошук «ідеального скальпеля» - інструменту, який дозволяє ефективно розсікати тканини 3 мінімальними пошкоджуючим ефектом забезпечуючи при цьому стійкий гемостаз. В зв'язку з цим, хірургічні методи лікування ХГ постійно піддаються еволюції [5].

Одним 3 порівняно нових напрямків в хірургічних клініках $\epsilon$ «електрозварка» біологічних тканин, заснована на принципі дозованої подачі модульованого струму, який автоматично генерується залежно від конкретного тканинного імпедансу. Тех- 
нологія електрозварювання в медицині завоювала міцні позиції завдяки тому, що забезпечує тканинно зберігаючий ефект при енергетичному впливі на оперований орган, який проявляється незначним деструктивним впливом на живу тканину, дозволяє виконувати одномоментно атравматичний розріз і коагуляцію практично без порушення морфоструктури тканини. Разом $з$ тим, залишаються невідомими результати використання методики зварювання при ГЕ та іï вПлив на морфологічні зміни тканин гемороїдального комплексу.

Мета дослідження. Покращити результати хірургічного лікування пацієнтів з ГХ шляхом встановлення впливу металевого скальпеля, діатермії та високочастотного біполярного електрокоагулятора на тканини гемороїдального комплексу за допомогою морфологічних досліджень.

Матеріали і методи дослідження. В основу дослідження покладено результати комплексного обстеження і лікування 180 пацієнтів із комбінованим XГ III-IV ст., які перебували на стаціонарному лікуванні в хірургічному відділенні Івано-Франківської центральної міської клінічної лікарні з 2012 по 2018 роки.

Серед прооперованих хворих переважали чоловіки, їх було 124 із 180 (68,9 \%; 95 \% ДІ 61,6-75,6 \%), відповідно жінок було 56 (31,1 \%; 95 \% ДІ 24,4$38,4 \%$ ). Переважання чоловіків ми можемо пояснити тим, що вони більше зайняті в сфері фізичної праці, у них частіше спостерігається порушення режиму харчування і наявність шкідливих звичок. Середній вік становив 41,3 $(35,6-49,3)$ роки.

Усім пацієнтам проводили трьох квадрантну ексцизійну ГЕ. Залежно від проведеного хірургічного лікування всі хворі були розподілені на 3 групи.У I групі пацієнтів (n=62) проводили класичну закриту ГЕ за Фергюсоном. В II групі пацієнтів $(\mathrm{n}=60)$ проводили ГЕ за Мілліганом-Морганом шляхом використання монополярного високочастотного струму коагулятором ERBEACC 450. В III групі пацієнтів (n=58) проводили ГЕ за Мілліганом-Морганом шляхом використання високочастотного електрозварювання м'яких тканин високочастотним електрокоагулятором ЕК-300М1.3 метою вивчення впливу монополярної коагуляції та біполярної коагуляції на тканину гемороїдального комплексу у досліджуваних хворих проводили гістологічні дослідження на базі навчально-наукової лабораторії морфологічного аналізу Івано-Франківського національного медичного університету.

Видалені гемороїдальні комплекси для гістологічних досліджень фіксували в $10 \%$ розчині нейтрального формаліну, зміну якого здійснювали через 12 і 24 години. Через 14 діб матеріал проводили до парафінових блоків, на санному мікротомі виготовляли зрізи товщиною 5 мкм, із наступним забарвленням гематоксиліном і еозином за загальноприйнятою методикою.

Отриманий матеріал від усіх пацієнтів фіксували у нейтральному $10 \%$ розчині формаліну та за стандартною методикою заливали у парафінові блоки. Далі за допомогою мікротома виготовляли зрізи матеріалу завтовшки 4-5 мкм. Депарафінізовані зрізи забарвлювали гематоксиліном і еозином для отримання загальної морфологічної характеристики структур та гістохімічного дослідження пікрофуксином за методом Ван Гізон.

Отримані гістологічні зрізи вивчали у світловому мікроскопі Micros Austria MC300 і фотографували цифровою фотокамерою Тoup Cam 5,1M UHCCD C-Mount Sony з адаптером ToupTek Photonics AMA075 за допомогою програмного забезпечення ToupView v. 3 (при збільшенні в $\times 200-1000$ разів).

$$
\text { Забір матеріалу для електронно- }
$$

мікроскопічного дослідження проводили за загальноприйнятими правилами. Півтонкі зрізи зафарбовували розчином метиленового синього, вивчали і документували так, як і гістологічні зрізи. Ультратонкі зрізи контрастували уранілацетатом на $70^{\circ}$ спирті і розчином Рейнольдса та вивчали в електронному мікроскопі ПЭМ-100К за умови прискорюючої напруги 75кВ. Електронограми оцифровували сканером EpsonPerfection V550 Photo з розширенням $1200 \mathrm{dpi}$.

3 метою статистичної обробки інформації бази даних формували в редакторі «Microsoft Excel 2010» (Microsoft, США). Для їх статистичної обробки використано програмне забезпечення «STATISTICA 10» (StatSoft, CША). Частоту якісних показників представляли в абсолютних (n) і відносних (\%) частотах зі вказанням $95 \%$-го довірчого інтервалу (ДІ) у вигляді «n $(\% ; 95 \%$ ДІ)». При цьому розраховували точні ДІ (з допомогою програмного забезпечення «R»). При аналізі кількісних даних обов'язково визначали характер розподілу значень показника, використовуючи для цього найбільш строгий 3 відомих методів - Shapiro-Wilk's W тест. Для кількісних даних 3 нормальним розподілом результати представляли у вигляді «М ( $\square$ )» (де $\mathrm{M}$ - середнє значення, $\mathrm{a} \square$ середнє квадратичне відхилення), або «М (95 \% ДІ)», а для кількісних даних 3 ненормальним розподілом у вигляді «медіана (25 і 75 процентилі)

Результати дослідження та їх обговорення. При світлооптичному дослідженні країв резекції гемороїдальних вузлів, видалених металевим скальпелем, діатермією або високочастотним біполярним електрокоагулятором, виявлено різні патоморфологічні зміни в тканинах залежно від інструменту видалення.

При дослідженні препаратів гемороїдальних вузлів, видалених металевим скальпелем або ножицями, при закритій ГЕ за Фергюсоном, спостерігається виражене геморагічне просякання слизової оболонки. При цьому, контури цих геморагій різноманітні, як і глибина їх поширення.

Тяжко диференціюються складові структури стінки у результаті геморагічно-дистрофічних процесів. Виявляються кровоносні судини із інфільтрованою і набряклою стінкою, а також тонкостінні. Однак, у всіх полях зору вони переповнені кров'ю і оточені набряклою стромою.

Сполучно-тканинний каркас дезорганізований. Тільки в окремих полях зору виявляються пучки набряклих колагенових волокон, а у більшості вони 
гомогенізовані і не мають притаманної їм у нормі впорядкованості (рис. 1).

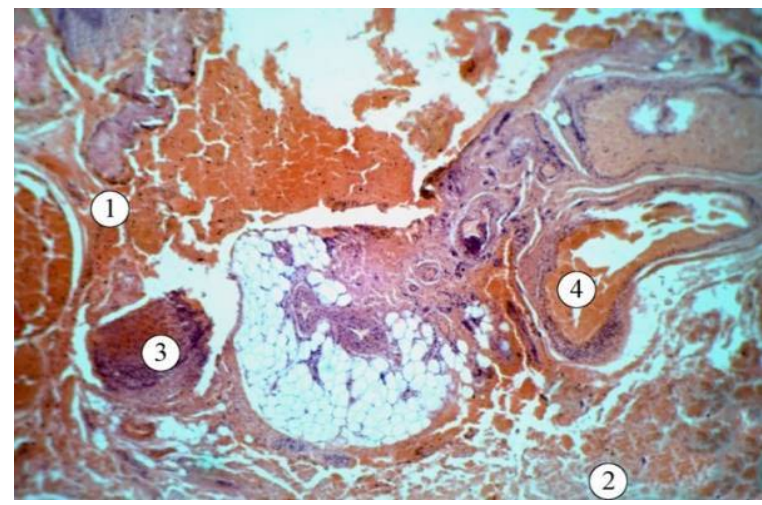

Рис. 1. Світлооптична оцінка морфологічного стану гемороїдальних вузлів, ектомованих класичним методом. 1 - геморагічно просякнута основна речовина, 2 - пучки дезорганізованих колагенових волокон, 3 - лімфоцитарна інфільтрація, 4 - виражені явища стазу. Забарвлення: гематоксилін і еозин. 3б.: $\mathbf{x 4 0}$

Хірургічний скальпель, характеризується малою інвазивністю i, як наслідок, найменшою пошкоджуючою дією на тканини, абсолютно не володіє гемостатичними властивостями, такими актуальними при операціях на багато васкуляризованих тканинах аноректальної області. Спеціальні додаткові заходи гемостазу (прошивання, лігування або електрокоагуляція судин) викликають додаткову травму, що характеризується різного ступеня вираженості деструкцією тканин і великими крововиливами в них.

Таким чином, після використання металевого скальпеля в краях хірургічного розтину відзначено поширені крововиливи, що свідчить про значну травматизацію тканин і в подальшому уповільнює загоєння рани та може перешкоджати загоєнню іï первинним натягом, призводячи до виникнення рубцевих змін.

Електронномікроскопічне дослідження підтверджує світлооптичні дані. В усіх полях зору множинні геморагії (рис. 2). Основна речовина позаклітинного матриксу просякнута плазмою, різноформні еритроцити виявляються за межами просвіту кровоносних судин. Дезорганізовані колагенові та еластичні волокна різної електронної щільності у результаті їх набряку.

У стінці кровоносних судин виявляються дистрофічні зміни. Як у артеріолах, так і в гемокапілярах ядра ендотеліоцитів деформовані, гетерохроматин займає маргінальне положення. Мембранні органели вакуолізовані. Базальна мембрана стоншена, фрагментована. Виражений сладж еритроцитів, адгезивні явища. Характерний паравазальний набряк. Тяжко візуалізуються фібробласти.

Світлооптичний аналіз препаратів гемороїдальних вузлів, отриманих в ході ГЕ за МілліганомМорганом монополярною електрокоагуляцією, свідчить про розвиток набрякових змін. При цьому, диференціюються епітелій у вигляді базофільної смужки та збережені кишкові залози.

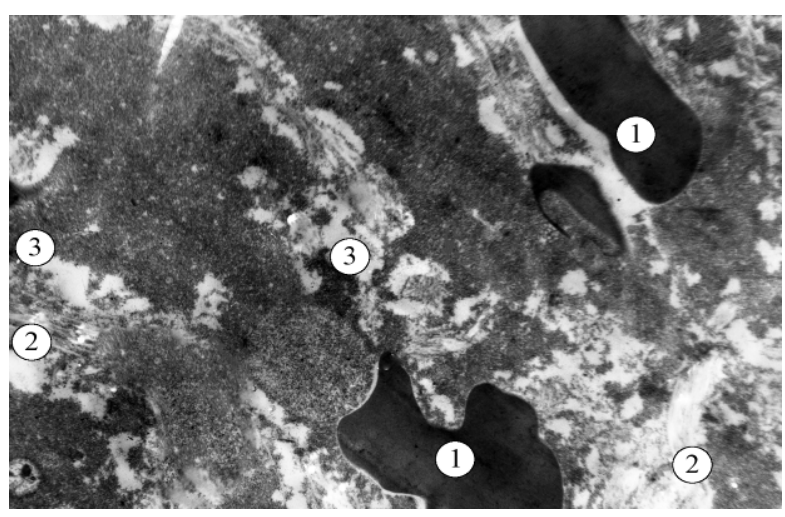

Рис. 2. Ультраструктура гемороїдальних вузлів, ектомованих класичним методом. Позначення: 1 - еритроцити, 2 - пучки волокон сполучної тканини, 3 - основна речовина. Електронна мікрофотографія. 3б.: 4000

Залозистий епітелій знаходиться на чітко контурованій базальній мембрані, просвіт заповнений гомогенним вмістом. У набряклій слизовій оболонці прослідковуються кровоносні судини із спастичними явищами у стінці.

Пучки колагенових та еластичних волокон розшаровані набряклою основною речовиною, помітна лімфоцитарна інфільтрація, і у небагатьох полях зору виявляються поодинокі локуси геморагій (рис.3).

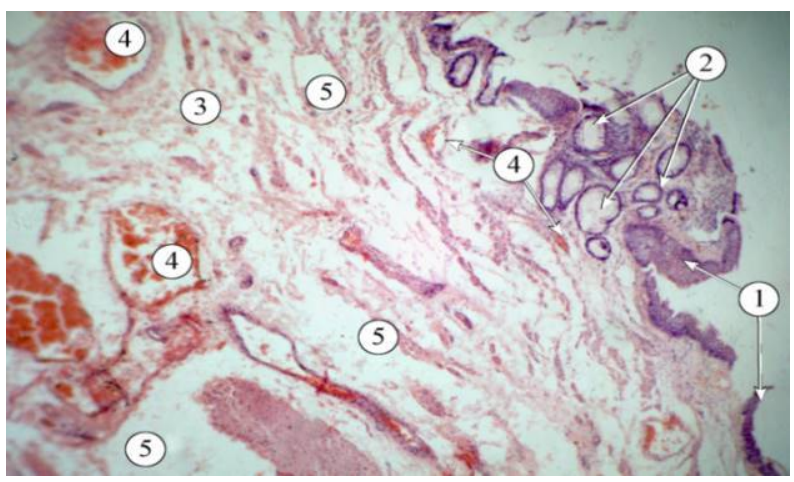

Рис. 3. Гістоструктура гемороїдальних вузлів, ектомованих монополярною електрокоагуляційною установкою. 1 - епітеліальна пластинка, 2 - кишкові залози, 3 - пучки колагенових волокон, 4 - явища стазу, 5 - едематозні зміни. Забарвлення: гематоксилін і еозин. 3б.: $\mathbf{x 4 0}$

При ультраструктурному дослідженні також помітна перевага набрякових змін у стінці ектомованих гемороїдальних вузлів монополярноюелектрокоагуляційною установкою. Стромальний компонент представлений деформованими та фрагментованими волокнами, які розрізнено пронизують едематозно змінену основну речовину. Дистрофічних змін зазнали і фібробласти. Тяжко диференціюються їх органели, які мають вигляд осміофільних гранул та мішечків; ядро із конденсованим хроматином.Дистрофічні зміни спостерігаються і у кровоносних судинах. Ендотеліоцити мають електроннощільне ядро та цитоплазму, в якій погано візуалізуються органели. У полях зору із зони коагуляційного некрозу є тільки 
фрагменти клітин в оточенні набряклої сполучної тканини (рис. 4).

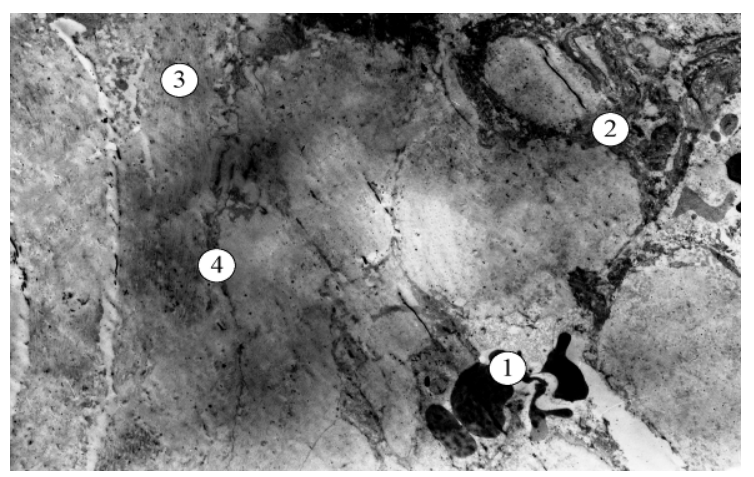

Рис. 4. Субмікроскопічні особливості гемороїдальних вузлів, ектомованих моно полярною електрокоагуляційною установкою. Позначення: 1 - еритроцитарний сладж, 2 - фрагмент ендотеліоцита, 3 - пучки дезорганізованих колагенових волокон, 4 - фрагмент відростка фібробласта. Електронна мікрофотографія. 3б.: 4800

Метод монополярної електрокоагуляції $\epsilon$ найбільш доступним і поширеним в Україні. Більшість авторів, які застосували високочастотний електрохірургічний апарат “ERBE ICC 200” для лікування пацієнтів 3 поєднаною патологією анального каналу і прямої кишки після операцій за відкритою методикою, під час розрізу тканин спостерігали утворенням тонкого шару коагуляційного некрозу товщиною в середньому $(0,286 \pm 0,15)$ мм [6]. Однак, аналізуючи отримані нами результати свідчать, що використання монополярної електрокоагуляції супроводжується рядом негативних наслідків: термічним ушкодженням тканини на неконтрольовану глибину, що призводить до опіку i некротичних змін навколишніх тканин i, як наслідок, до розвитку запалення, що подовжує терміни загоєння рани, до деформації і формування грубої рубцевої тканини; можливістю зупинити тільки капілярну кровотечу, тобто перекрити судину діаметром до 1 мм; налипанням тканини на наконечник інструменту, що знижує ефективність і вимагає його чистки, подовжуючи оперативне втручання; підвищеним утворенням токсичного диму неприємним запахом під час виконання гемостазу.

Дослідження гістоструктури гемороїдальних вузлів, видалених біполярним високочастотним електрокоагулятором ЕК-300М1, показало менш виражені морфологічні зміни, порівняно із іншими методами ектоміі. Характерна чітка стратифікація. Шар коагуляційного некрозу має вигляд слабо еозинофільної гомогенної тонкої смужки. Тинкторіальні властивості епітелію збережені. Добре виражена базофілія епітеліоцитів дна кишкових залоз. Колагенові волокна організовані в пучки, які чітко прослідковуються в усіх полях зору, хоча й подекуди розшаровані незначно набряклою основною речовиною позаклітинного матриксу. Помітні явища стазу у дрібних судинах, однак геморагічні просякання $є$ локальними і виявляються не в усіх полях зору (рис. 5).

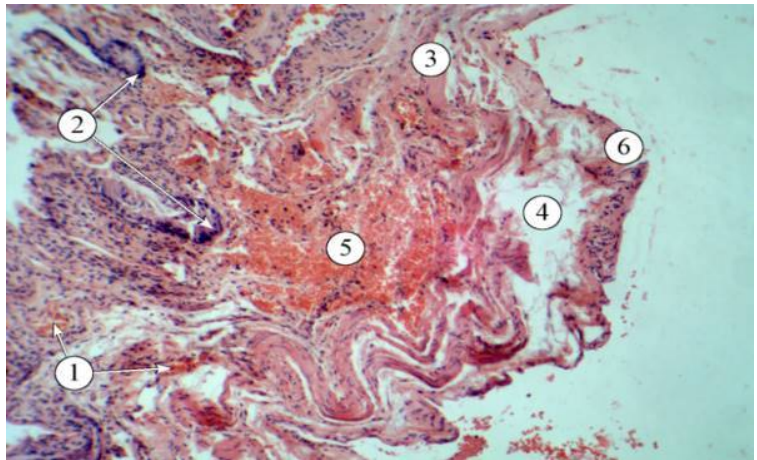

Рис. 5. Гістоструктура гемороїдальних вузлів, ектомованих біполярним високочастотним елетрокоагулятором. 1 - явища венозного стазу, 2 - дно кишкових залоз, 3 - пучки колагенових волокон, 4 - набряк основної речовини, 5 - геморагічне просякання сполучної тканини, 6 - тонкий шар коагуляційного некрозу. Забарвлення: гематоксилін і еозин. 3б.: х100

Субмікроскопічне дослідження тканин гемороїдальних вузлів біля зони коагуляційного некрозу засвідчило збереженість стромального компоненту, хоча він деформований. Так, колагенові волокна візуалізуються пучками з різною електронною щільністю, а еластичні волокна у вигляді фрагментів звивистих смужок. Основна речовина оптично прозора, містить множинні преципітати коагульованих білків та їх полімерів.

У просвіті кровоносних судин виявляються фрагменти формених елементів та коагульовані маси плазми (рис. 6). Базальна мембрана по периметру оточує судини, в іiі розщепленнях візуалізуються перицити. Ендотеліоци тидистрофічно змінені із утрудненою ідентифікацією органел. Для того, щоб відновлення фізіологічних функцій оперованого органу або тканини відбувалось досить швидко і не викликало ускладнень, термічний вплив має бути, 3 одного боку, мінімальним, $з$ іншого - достатнім для отримання надійного гемостазу або з'єднання. Після використання високочастотного біполярного електрокоагулятора ЕК-300M1 розтин тканин здійснювався шляхом їх розсічення та коагуляції з контролем гемостазу та утворенням тонкого шару коагуляційного некрозу.

Поруч із зоною коагуляції знаходяться практично незмінені тканини і судини. Збереження оточуючих зону коагуляції тканин має важливе прогностичне значення в силу того, що вони дадуть можливість швидкого загоєння післяопераційного розрізу. Схожі результати отримані іншими авторами, які використовували метод високочастотного зварювання м'яких тканин. У видалених гемороїдальних комплексах поряд з гомогенізованою тканиною присутня велика кількість тканинних компонентів, структурно непошкоджених клітин, що створює очевидні передумови для подальших репаративних процесів. Основними факторами надійного і специфічного гемостазу, зумовленого застосуванням високочастотного електротермічного генератора $\epsilon$ : формування тромбів i тканинної анізотропії в стінках самих судин, що призводить до «гофрування», зморщування їх просвіту та 
формування специфічної аутобілкової тканини у вигляді пломби (аутобіоклею), що фіксує тканину в положенні, зумовленому механічним впливом бранш інструменту [7].

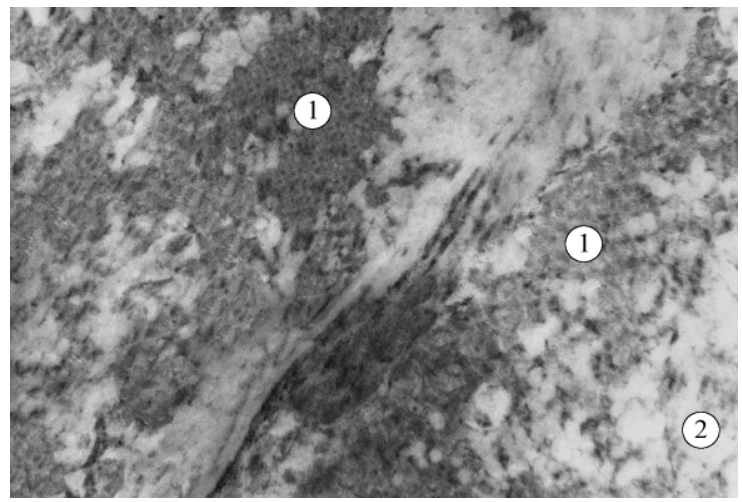

Рис. 6. Електронномікроскопічні особливості будови гемороїдальних вузлів, ектомованих біполярним високочастотним електрокоагулятором. Позначення: 1 - пучки колагенових волокон, 2 - основна речовина. Електронна мікрофотографія. Зб.: 6400

Таким чином, при класичній закритійГЕ за Фергюсоному стінці кишки спостерігаються геморагічно-дистрофічні процеси, виражена дезорганізація сполучно-тканинних складових. При ГЕ за Мілліганом-Морганом моно полярною електрокоагуляційною установкою у стінці кишки домінують набрякові зміни. При ГЕ за Мілліганом-Морганом біполярним високочастотним електрокоагулятором фіксується тонкий шар коагуляційного некрозу, збереженість оболонкової будови стінки кишки. $\mathcal{E}$ незначний набряк міжклітинної основної речовини і явища стазу у дрібних судинах, мозаїчні острівці геморагічного просякання.

Висновки. Застосування електрокоагулятора ЕК-300M1 характеризується контрольованою, щадливою дією на тканини. Зона латерального некрозу після біполярної коагуляції менша, ніж після застосування звичайної діатермії. Дисекція та коагуляція за допомогою електокоагулятора ЕК-300M1 характеризується суворо локальним ефектом, наявністю “біологічного зварювання” шарів органу, який розсікали та супроводжується надійним гемостазом. Окрім того, метод високочастотного зварювання біологічних тканин характеризується відсутністю таких негативних наслідків, які виникають від застосування інших високочастотних електрогенераторів, як карбонізація тканин, відстрочене поширення коагуляційного некрозу, дистанційне пошкодження органів.

Перспективи подалыших досліджень у цьому напрямку. Встановити клінічну ефективність використання високочастотних струмів при ексцизійних ГЕ.

\section{References:}

1. Agarwal N, Singh K, Sheikh P, Mittal K, Mathai V, Kumar A. Executive Summary - The Association of Colon \& Rectal Surgeons of India (ACRSI) Practice Guidelines for the Management of Haemorrhoids. 2016. Indian J Surg. 2017;79:58-61.
2. Brown S, Tiernan J, Biggs K, Hind D, Shephard N, Bradburn $\mathrm{M}$ et al. The HubBLe Trial: haemorrhoidal artery ligation (HAL) versus rubber band ligation (RBL) for symptomatic second- and third-degree haemorrhoids: a multicentrerandomised controlled trial and healtheconomic evaluation. HealthTechno1Assess. 2016;20:1-150.

3. Davis BR, Lee-Kong SA, Migaly J, Feingold DL, Steele SR. The American Society of Colon and Rectal Surgeons Clinical Practice Guidelines for the Management of Hemorrhoids. DisColonRectum. 2018;61:284-292.

4. Gerbershagen HJ, Aduckathil S, van Wijck AJ, Peelen LM, Kalkman CJ, Meissner W. Pain intensity on the first day after surgery: a prospective cohort study comparing 179 surgical procedures. Anesthesiology. 2015;118:934-944.

5. Emile SH. Evidence based review of methods used to reduce pain after excisional hemorrhoid ectomy. J.coloproctol. 2019;39(1):81-89.

6. Zakharash MP, Balytskyi VV, Kuryk $\mathrm{OH}$. Zastosuvannia vysokochastotnoho elektrokhirurhichnoho aparata ERBE ICC 200 dlia likuvannia patsiientiv $\mathrm{Z}$ poiednanoiu patolohiieiu analnoho kanalu i priamoi kyshky.Klinichna khirurhiia. 2018 March; 85 (3):14-16

7. Hryntsov AH, Sovpel OV, Kunytskyi YuL, Yudin VN, Shapovalova YuA. Vykorystannia biolohichnoho zvariuvannia tkanyn pry vykonanni hem0roiektomii. Visnyk Ukrainskoi medychnoi stomatolohichnoi akademii. 2015, Tom 7, Vypusk 1-2:269-271

УДК 616.352-089-06 С-605

СВЕТООПТИЧЕСКИЕ И СУБМИКРОСКОПИЧЕСКИЕ ОСОБЕННОСТИПАТОЛОГИЧЕСКИХ ИЗМЕНЕНИЙ В ГЕМОРРОИДАЛЬНЫХ УЗЛАХ, УДАЛЕННЫХ РАЗЛИЧНЫМИ ИНСТРУМЕНТАМИ

\section{В.Д. Скрипко ${ }^{1}$, О.Г.Попадынец ${ }^{2}$, П.В. Соломчак ${ }^{1}$}

\author{
Ивано-Франковский нацчиональный медицинский \\ университет, \\ ${ }^{1}$ кафедра хирургииННИ ПО, \\ ${ }^{2}$ кафедра анатомии человека, \\ 2. Ивано-Франковск, Украина, \\ ORCID ID: 0000-0003-0670-8600, \\ ORCID ID: 0000-0002-1555-2030, \\ ORCID ID: 0000-0002-2093-5984, \\ e-mail: solopetro@gmail.com
}

Резюме. Геморойектомия - это операция, при которой удовлетворенность пациентов низкая, хотя это часто выполняемая операция в современной хирургической практике. Основной причиной недовольства является выраженная послеоперационная боль и другие осложнения. Значительная часть осложнений связана с видом хирургического инструмента, которым удаляется геморроидальный комплекс. Актуальным является поиск инструмента, который позволяет эффективно рассекать ткани с минимальными повреждающими эффектами. С целью изучения влияния металлического скальпеля, 
диатермокоагуляции и биполярной коагуляции на ткань геморроидального комплекса в исследуемых больных проводили гистологические исследования.

Приклассической закрытой геморойектомии за Фергюсонв стенке кишки наблюдаются геморрагически-дистрофические процессы, выраженная дезорганизация соединительнотканных составляющих. Пригеморойектомии за Миллиганом-Морганом, выполненной монополярной електрокоагуляционной установкой у стенки кишки доминируют отечные изменения. При геморойектомии за МиллиганомМорганом путем использования высокочастотной электросварки мягких тканей фиксируется тонкий слой коагуляционного некроза, сохранность оболочечного строения стенки кишки. Есть незначительный отек межклеточного основного вещества и явления стаза в мелких сосудах, мозаичные островки геморрагического пропитывания.

Применение метода высокочастотной электросварки мягких тканей характеризуется контролируемым, щадящим действием на ткани, зона латерального некроза после биполярной коагуляции меньше, чем после применения обычной диатермии. Диссекция и коагуляция с помощью биполярного высокочастотного електокоагулятора ЭК 300 М1характеризуется строго локальным эффектом, наличием "биологической сварки" слоев, органа который рассекали и надежным гемостазом.

Ключевые слова: геморойектомия, металлический скальпель, диатермия, биполярная электрокоагуляция, морфологические изменения.

\section{UDC 616.352-089-06 C-605 \\ OPTICAL AND SUBMICROSCOPIC FEATURES OF PATHOLOGICAL CHANGES IN HEMORRHOIDS REMOVED BY VARIOUS INSTRUMENTS}

\author{
V.D. Skrypko ${ }^{1}$, O.G. Popadynets ${ }^{2}$, P.V. Solomchak ${ }^{1}$ \\ Ivano-Frankivsk National Medical University, \\ ${ }^{1}$ Department of Surgery of Educational-Scientific \\ Institute of Postgraduate Education, \\ ${ }^{2}$ Departmentofhuman anatomy, \\ Ivano-Frankivsk, Ukraine, \\ ORCID ID: 0000-0003-0670-8600, \\ ORCID ID: 0000-0002-1555-2030 \\ ORCID ID: 0000-0002-2093-5984, \\ e-mail: solopetro@gmail.com
}

Abstract. Despite the rapid development of lowinvasive technologies in the treatment of hemorrhoids, the operation offered by Milligan - Morgan and Ferguson remains nowadays the most radical intervention of hemorrhoids of the $3 \mathrm{~d}$ and 4 th degree. In the accumulation of experience, hemorrhoectomy according to MilliganMorgan and Ferguson had undergone a number of changes. Technical progress and the latest medical equipment contributed to the wide development of various modifica- tions of this surgical intervention, which prompted us to study the peculiarities of the use of electrocoagulation equipment. Hemorrhoectomy is an operation in which patient satisfaction is low, although it is a commonly performed operation in modern surgical practice. The main cause of dissatisfaction is pronounced postoperative pain, acute urinary retention, postoperative bleeding, suppuration of the wound and other complications. Much of the complication is related to the type of surgical instrument that removes the hemorrhoid complex. It is important to find a tool that allows you to effectively dissect fabrics with minimal damaging effects. In the conditions of the Surgical Department of the Central City Clinical Hospital $(\mathrm{CCCH})$ in Ivano-Frankivsk for the period of 2012-2018, 180 patients with the $3 \mathrm{~d}$ and 4th degree of hemorrhoids were operated successfully. All patients perform a three-quadrant hemorrhoectomy. Depending on the surgical treatment, all patients were divided into 3 groups. In the first group of patients $(n=62)$, a classic closed hemorrhoectomy was performed. In the second group of patients $(n=60)$, they performed the hemorrhoectomy by Milligan-Morgan using monopolar high-frequency current. In the third group of patients $(\mathrm{n}=$ 58 ), they performed the hemorrhoectomy by MilliganMorgan using high-frequency soft tissue welding. In order to study the effect of metal scalpel, diathermocoagulation and bipolar coagulation on the tissue of the hemorrhoid complex in the studied patients, histological studies were performed.

In the classic closed hemorrhoectomy according to Ferguson hemorrhagic-dystrophic processes are observed in the intestinal wall, disorganization of connective tissue components is expressed. In the case of hemorrhoectomy by Milligan-Morgan, a monopolar electrocoagulation unit in the bowel wall is dominated by edema. In the case of hemorrhoectomyby Milligan-Morgan, a bipolar high-frequency electrocoagulator captures a thin layer of coagulation necrosis, preservation of the shell structure of the intestinal wall. There is slight swelling of the intercellular basic substance and the phenomenon of stasis in small vessels, mosaic islets of hemorrhagic impregnation.

The use of bipolar high frequency coagulation is characterized by a controlled, sparing effect on the tissues, the area of lateral necrosis after bipolar coagulation is smaller than after the use of conventional diathermy. Dissection and coagulation using a bipolar highfrequency coagulator is characterized by a strictly local effect, the presence of "biological welding" of layers, the organ being dissected and reliable hemostasis. Electron microscopic examination confirms the optical data. According to the results of the performed study, the following conclusions is drawn: the use of the bipolar current of the electrosurgical equipment during the operation of Milligan-Morgan has advantages over the classical methods of its performance.

Keywords: hemorrhoectomy, metal scalpel, diathermy, bipolar electrocoagulation, morphological changes.

Стаття надійшла в редакцію 05.03.2020 p. 